\title{
The Need for a Legal Distinction of Nutraceuticals
}

\author{
Annemarie Koch, Sonja Brandenburger, Suzanne Türpe, Marc Birringer* \\ Department of Nutritional, Food and Consumer Studies, University of Applied Sciences Fulda, Fulda, Germany \\ Email: ${ }^{*}$ marc.birringer@he.hs-fulda.de
}

Received 8 March 2014; revised 8 April 2014; accepted 15 April 2014

Copyright (C) 2014 by authors and Scientific Research Publishing Inc.

This work is licensed under the Creative Commons Attribution International License (CC BY). http://creativecommons.org/licenses/by/4.0/

(c) (i) Open Access

\begin{abstract}
The nutraceutical and botanical terms are often used by the lay press or for marketing purposes to describe health beneficial food, food supplements or herbs. However, there is no common definition of nutraceuticals or botanicals and moreover a lack of regulation that classifies this category. Concerning their health value, it is unclear if they belong to drugs or food. Currently, they fall into a legal limbo between both. This regulatory lack can lead to misuse of claims indicating a health benefit or the misleading of the consumer. This review will focus on current definitions of nutraceutical, botanical, functional food and food supplements with special emphasis on the differences between the US and European legislation. Some special considerations will be given for Germany, one of the main markets for food supplements in Europe.
\end{abstract}

\section{Keywords}

\section{Nutraceutical, Botanical, Food Supplement, Definition, Legislation}

\section{Introduction}

In recent years, the interest in a healthy lifestyle by prevention (with aid of nutrition) or self-medication with aid of natural products increased [1]. Nevertheless, the number of diseases like coronary heart disease, diabetes or adiposity increased [2]. In this respect, so called nutraceuticals and botanicals have one of the highest market potential in the food sector. This aspect has been recently summarized by an excellent review of Nicoletti [3]. The name nutraceutical is a composition of the terms nutrient and pharmaceutical [4]. Botanicals were often used as a synonym for herbs or herbal products with medicinal potency. Nutraceuticals as well as botanicals can be legally bought in pharmacies, supermarkets or online shops and sold as part of a normal diet. They contain substances, which could be beneficial for health by preventing or treating one or more diseases [5]. In that way,

"Corresponding author. 
they respond to the desire today's consumer for self-medication and prevention of disease risks.

There are an increasing number of nutraceutical supplements emerging in a variety of distribution channels, especially in the internet-based sales. At the same time, safety concerns of the governmental authorities lag behind the marketing strategies of distributers. In other words, there are more and more supplements with scarce scientific evidence of their medicinal potency, no or little control of their composition, no control of their shelflive and no knowledge of side effects or supplement-drug interactions [6]-[8]. Since the legal status of nutraceuticals and botanicals is in a grey zone, a risk management or action plan for these supplements controlled by governmental authorities is widely missing. In addition, new problems emerge if a "Transatlantic Trade and Investment Partnership" (TTIP) will come into force between the US and Europe.

The aim of this review is to compile adequate definitions of nutraceutical, botanical, functional food and food supplements with special emphasis on the differences between the US and European legislation. Some special considerations will be given for Germany, one of the main markets for food supplements in Europe.

\section{Definitions of Nutraceuticals}

Nutraceuticals supposed to have a defined physiological effect; therefore they do not easily fall into the legal categories of food or drug. Nutraceuticals inhabit a legal grey area between both and can be shifted depending on the (medicinal) purpose of the product on one side and the nutritional value on the other (illustrated in Figure 1). The lack of a common universal definition and the interchangeable use of "functional food" and "nutraceutical" cause legal problems either by selling corresponding products as over-the-counter (OTC) remedies or classification by governmental admission boards.

Consumers, public authorities and researchers face the problem that there is no generally accepted definition for nutraceuticals and botanicals [3]. The word nutraceutical is a combination of nutrition and pharmaceutical. The word was first created by Stephen DeFelice, who defined nutraceuticals as "any substance considered a food or part of a food which provides medical or health benefits including the prevention or treatment of disease..." [4]. Nutraceuticals can "(1) be part of an intact food source [...]; (2) be part of a processed food [...]; (3) be fortified or enriched substance in a food [...]; or (4) be provided in supplemental form” [5]. Table 1 presents a list of available definitions for nutraceuticals from literature and online resources. As stated by Shahidi "in all cases, the main focus is on improving health and reducing disease risk through, mainly, prevention” [15].

\section{Definitions of Botanical}

According to the Office of Dietary Supplements [16] a "botanical is a plant or plant part valued for its medicinal or therapeutic properties, flavour, and/or scent. Herbs are a subset of botanicals. Products made from botanicals that are used to maintain or improve health may be called herbal products, botanical products, or phytomedicines". A collection of some more definitions is presented in Table 2 to show their variation.

Nutraceuticals are foods or any natural substances that contain (naturally or supplemented) ingredients purported to have health benefits [12]. Nutraceuticals are sold as functional foods or food supplements. Botanicals are nutraceuticals made from plant parts [17], so they can be seen as nutraceuticals. As exception they can also be considered as medicinal food. Food supplements can be divided into either supplements with vitamins and minerals which belong to nutraceuticals or supplements with "other" substances which include botanicals and other physiologically active natural substances.

To clarify and work on this topic the authors try to agree on the following classification (Figure 2).

\section{Legal Distinction of Nutraceutical and Functional Food in the US}

The terms "nutraceutical" and "functional food" is not recognised legally in the USA [3] [4] [21]. But as the author's classification indicates, products with nutraceutical actives are sold as either functional foods or food supplements in the US marketplace [4]. Table 3 shows the US regulatory framework for food in pharmaceuticals. Nutraceuticals or functional food cut across the different categories so it depends on the product, which regulation should be applied [4].

"Functional food" is mainly a marketing term, so there is no regulatory definition, but some organisations prepared definitions for the fast growing category of functional foods [4] [21]. For example, the International Food Information Council (IFIC) considers that functional food is "any food or food component that may have 


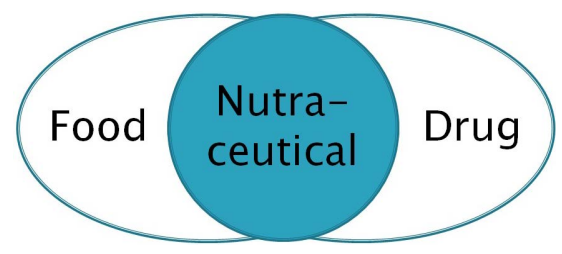

Figure 1. Nutraceutical occupies position between food and drug according to [9].

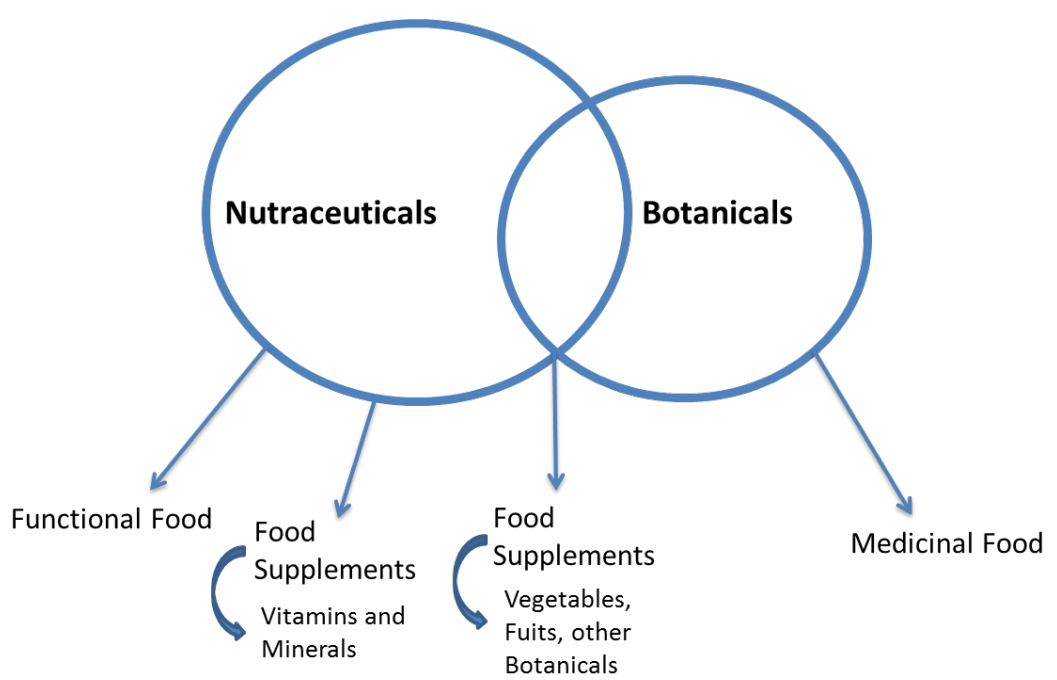

Figure 2. Relationship between nutraceuticals and botanicals.

Table 1. Definition of neutraceutical.

Definition of nutraceutical

"A nutraceutical is any substance considered a food or part of a food which provides medical or health benefits including the prevention or treatment of disease and include isolated nutrients, dietary supplements, diets and dietary plans, genetically engineered foods, herbal products and processed foods such as cereals soups and beverages.”

DeFelice cited [4]

"Chemicals found as a natural component of foods or other ingestible forms that have been determined to be beneficial to the human body in preventing or treating one or more diseases or improving physiological performance. Essential nutrients can be considered nutraceuticals if they provide benefit beyond their essential role in normal growth or maintenance of the human body"

$\rightarrow$ Functional Food: “A food, either natural or formulated, which will enhance physiological performance or prevent or treat diseases and disorders."

"[...] functional food provides the body with the required amount of vitamins, fats, proteins, carbohydrates, etc, nedded for its healthy survival. When functional food aids in the prevention and/or treatment of disease(s) and/or disorder(s) other than anemia, it is called a nutraceutical.”

A "food or natural substance that contains or is supplemented with ingredients purported to have health benefits."

"A food or naturally occurring food supplement thought to prevent disease or have other beneficial effects on human health. Also called functional Food.”

"[...] According to this conventional view, foodstuffs primarily provide nutrition in the form of substances which the human body needs for normal development and maintenance of bodily functions. Medicines, on the other hand, are always seen as therapeutic agents in the context of disease and health. The more knowledge is obtained about the health-promoting effect of foods, the more blurred this seemingly strict separating line becomes between these two product groups. This is reflected in the word nutraceutical combining both the idea of nutrition and the concept of the pharmaceutical. And it is now a well established term.”

"A nutraceutical is a product isolated or purified from foods that is generally sold in medicinal forms not usually associated with food. A nutraceutical is demonstrated to have a physiological benefit or provide protection against chronic disease.”

$\rightarrow$ "A functional food is similar in appearance to, or may be, a conventional food, is consumed as part of a usual diet, and is demonstrated to have physiological benefits and/or reduce the risk of chronic disease beyond basic nutritional functions.” 
Table 2. Definition of botanical.

"A botanical is a plant or plant part valued for its medicinal or therapeutic properties, flavor, and/or scent. Herbs are a subset of botanicals. Products made from botanicals that are used to maintain or improve health may be called herbal products, botanical products, or phytomedicines.”

A “drug made from part of a plant, as from roots or bark."

"A drug, medicinal preparation, or similar substance obtained from a plant or plants."

A "substance obtained from a plant and used typically in medincinal or cosmetic products."

Botanical Drug Product: A product that is used as a drug and that contains as ingredients vegetable materials, which may include plant materials, algae, macroscopic fungi, or combinations thereof. Botanical drug products may be available as (but are not limited to) solutions (e.g., teas), powders, tablets, capsules, elixirs, topicals, or injectables. For the purposes of this MAPP, fermentation products and highly purified (or chemically modified) botanical substances are not considered botanical drug products. See the Botanical Guidance for a more comprehensive definition of botanical products. Allergenic extracts and vaccines that contain botanical ingredients are regulated by the Center for Biologics Evaluation and Research (CBER) under section 351 of the Public Health Service Act (42 U.S.C. 262).

Table 3. US regulations for food and drugs according to [4].

\begin{tabular}{|c|c|c|c|c|c|}
\hline \multirow{2}{*}{$\begin{array}{l}\text { Food Ingredients } \\
\text { with a health } \\
\text { benefit }\end{array}$} & \multicolumn{4}{|c|}{ Food and Beverage Products } & \multirow[b]{2}{*}{ Drug } \\
\hline & Food/Beverage & Dietary Supplement & $\begin{array}{l}\text { Food For Special } \\
\text { Dietary Use (FSDU) }\end{array}$ & Medical Food & \\
\hline \multicolumn{6}{|c|}{ Nutraceutical } \\
\hline $\begin{array}{l}\text { Food Additives and } \\
\text { Ingredients } \\
\text { - } \text { Significant safety } \\
\text { evidence required } \\
\text { Documented safe } \\
\text { only for an } \\
\text { intended use } \\
\text { - } \\
\text { Food Additive } \\
\text { Petitions (FAPs): } \\
\text { 2-12 years for } \\
\text { approval } \\
\text { Petition for } \\
\text { approval required } \\
\text { for compounds } \\
\text { foreign to the } \\
\text { human body } \\
\text { Gras Ingredient } \\
\text { (Generally } \\
\text { Recognized As } \\
\text { Safe): } \\
\text { Evaluation } \\
\text { undertaken for } \\
\text { substances } \\
\text { expected to be } \\
\text { safe } \\
\text { Independent } \\
\text { Expert Panel } \\
\text { Review for } \\
\text { Safety } \\
\text { GRAS } \\
\text { notification } \\
\text { process can be } \\
\text { much shorter } \\
\text { than for FAPs } \\
\text { Can self-affirm } \\
\text { GRAS status in } \\
\text { some } \\
\text { circumstances }\end{array}$ & $\begin{array}{ll}\text { Claims } \\
\text { - } & \text { Nutrient contel } \\
\text { - } & \text { FDAMA claim } \\
\text { authoritative sc } \\
\text { (usually gov't) } \\
\text { - } \quad \text { Food And Dru } \\
\text { Modernization } \\
\text { - } \quad \text { Structure/funct } \\
\text { formal approva } \\
\text { indicated whic } \\
\text { - } \quad \text { Claims obtaine } \\
\text { - } \quad \text { Non-qualified } \\
\text { meet significar } \\
\text { standard } \\
\text { - Qualified Heal } \\
\text { statements indi } \\
\text { inconclusive sc } \\
\text { behind them }\end{array}$ & $\begin{array}{l}\text { ent claims } \\
\text { ms, from an } \\
\text { scientific source } \\
\text { t) } \\
\text { ug Administration } \\
\text { n Act } 1997 \\
\text { ction claims require no } \\
\text { val, but FDA has } \\
\text { ch they will accept } \\
\text { led by petition: } \\
\text { l health claims must } \\
\text { ant scientific agreement } \\
\text { alth claims have } \\
\text { dicating the level of } \\
\text { scientific support }\end{array}$ & $\begin{array}{ll}\text { FSDU } \\
\text { - } & \text { Foods used to } \\
\text { supply } \\
\text { particular } \\
\text { dietary needs } \\
\text { that exist } \\
\text { because of a } \\
\text { physical, } \\
\text { physiological } \\
\text { or pathological } \\
\text { condition } \\
\text { - } & \text { Fall under } \\
\text { NLEA } \\
\text { regulations } \\
\text { - Examples are } \\
\text { - } & \text { Hypoallergenic } \\
\text { foods } \\
\text { - } \quad \text { Infant foods } \\
\text { - Meal } \\
\text { replacements } \\
\text { for weight } \\
\text { management }\end{array}$ & $\begin{array}{ll}\text { Medical Food } \\
\text { - } & \text { For managing } \\
\text { diseases that } \\
\text { have specific } \\
\text { nutritional } \\
\text { requirements } \\
\text { - } & \text { For use with } \\
\text { medical } \\
\text { supervision } \\
\text { - } & \text { Exempt from } \\
\text { NLEA } \\
\text { labelling } \\
\text { - Insurance } \\
\text { covers cost if } \\
\text { given by } \\
\text { feeding tube } \\
\text { - Few } \\
\text { regulations } \\
\text { because } \\
\text { market } \\
\text { "regulate" } \\
\text { itself } \\
\text { regarding } \\
\text { product } \\
\text { composition } \\
\text { and claim }\end{array}$ & $\begin{array}{ll}\text { OTC/RX } \\
\text { - } & \text { Musst meet } \\
\text { FDA premarket } \\
\text { approval } \\
\text { requirements } \\
\text { - } & \text { Substantial } \\
\text { safety and } \\
\text { efficacy data } \\
\text { required } \\
\text { - May claim to } \\
\text { diagnose, cure, } \\
\text { mitigate, treat } \\
\text { or prevent } \\
\text { disease } \\
\text { High } \\
\text { investment and } \\
\text { strong scientific } \\
\text { core } \\
\text { competencies } \\
\text { required } \\
\text { Long time to } \\
\text { develop New } \\
\text { Drug } \\
\text { Application } \\
\text { (NDA) } \\
\text { Approval } \\
\text { process of } \\
\text { qualified NDAs } \\
\text { in } 2 \text { years or } \\
\text { less }\end{array}$ \\
\hline
\end{tabular}


health benefits beyond basic nutrition” [21]. A functional food could be a product with added nutrients, which promotes health or it could be a product which has a functional component [4]. The regulation for the use of so called health claims is determined in the Nutrition Labelling and Education Act of 1990 and the Code of Federal Regulations 21 CFR 101.93 and Federal Register 65 FR 1000. Health claims are statements about the ability to reduce the risk of diseases, health-related conditions, or refer to effects on the structure or function of the human body [22] [23].

\section{Legal Distinction of Nutraceutical and Functional Food in Europe}

Within European Union (EU) law the legal categorization of a nutraceutical and functional food, strongly depends on the purpose of its use. In 2006, just before the release of the Health Claims Regulation (EC) No. 1924/2006, Coppens and Gulati published two comprehensive reviews with a decision making tree distinguishing the law category in which these supplements fall into [9] [24].

In the EU food is defined in the Regulation (EC) No. 178/2002 as "any substance or product [...] intended to be, or reasonably expected to be ingested by humans" and shall not include feed, live animals, plants prior to harvesting, medicinal products, cosmetics, tobacco, narcotic or psychotropic substances, residues and contaminants [25]. The term "functional food" is not legally defined in the EU [26]. The European Commission Concerted Action on Functional Food Science in Europe (FUFOSE) defines it as "a food that beneficially affects one or more target functions in the body beyond adequate nutritional effects in a way that is relevant to either an improved state of health and well-being and/or reduction of risk of disease” [26]. In addition, a functional food is consumed as part of a normal diet and is not a dietary supplement.

Because of the increasing interest in a healthy lifestyle and the consumers' awareness of the link between food and health, many products appeared on the market claiming health and well-being [26] To ensure that these claims are not misleading the consumer the European Commission passed a regulation on these claims the so called Health Claim Regulation in 2006. This Regulation ((EC) No. 1924/2006) acts additionally to the Regulation (EC) No. 178/2002 and contains the definitions of nutrition and health claims, the conditions of use and the authorisation of health claims [27]. The register of the approved health claims is published on the website of the European Commission. The health claims can be separated into 1) reduction of disease risk claims and 2) claims other than referring to the reduction of disease risk [27]. The latter means claims, which indicates a contribution 1) to growth, development and the functions of the body, 2) to psychological and behavioural functions or 3) weight control. Further information on this regulation is provided in paragraph 3.2 Food supplements (p. 19).

In conclusion, as for the EU functional food is basically regulated in the general food law regulation (Regulation (EC) No. 178/2002) and to control the claims referring to health, the EU introduced the health claim regulation (Regulation (EC) No. 1924/2006) to avoid the misleading of the consumer.

All these guidelines apply for European countries (Table 4). In Germany it co-exists the Regulation on Food Supplements (in German: Nahrungsergänzungsmittelverordnung; short form: NemV). This regulation includes a definition, the composition, the packaging and the labelling as required in Directive 2002/46/EC. An additional and strict announcement is that the manufacturers have to send a sample of the label to the Federal Office of Consumer Protection and Food Safety. The ordinance on food supplement contains regulations on administrative offence and criminal actions. The second national regulation is the Regulation on Dietary Foods (in German: Diätverordnung; short form: DiätV). "Dietary foods are foods which correspond to the special nutritional requirements of specific groups of people.” They must be suitable for a special nutritional purpose and must be clearly distinguishable from foods for general consumption. Also the Regulation contains special provisions for specific groups of dietary foods such as foods for infants and small children. The groups of dietary foods for which special provisions have already been issued or for which individual provisions are going to be issued, are listed in Annex 8 to $§ 4 a$ para 1 DiätV [28].

\section{Legal Distinction of Botanical in the US and Europe}

In the US there is no specific regulation for botanicals. However, the Office of Dietary Supplements gives some advices and a definition for botanicals. According to this institution, "a botanical is a plant or plant part valued for its medicinal or therapeutic properties, flavour, and/or scent. Herbs are a subset of botanicals. Products made from botanicals that are used to maintain or improve health may be called herbal products, botanical products, or phytomedicines.” [16]. 
Table 4. European regulations for food and drugs.

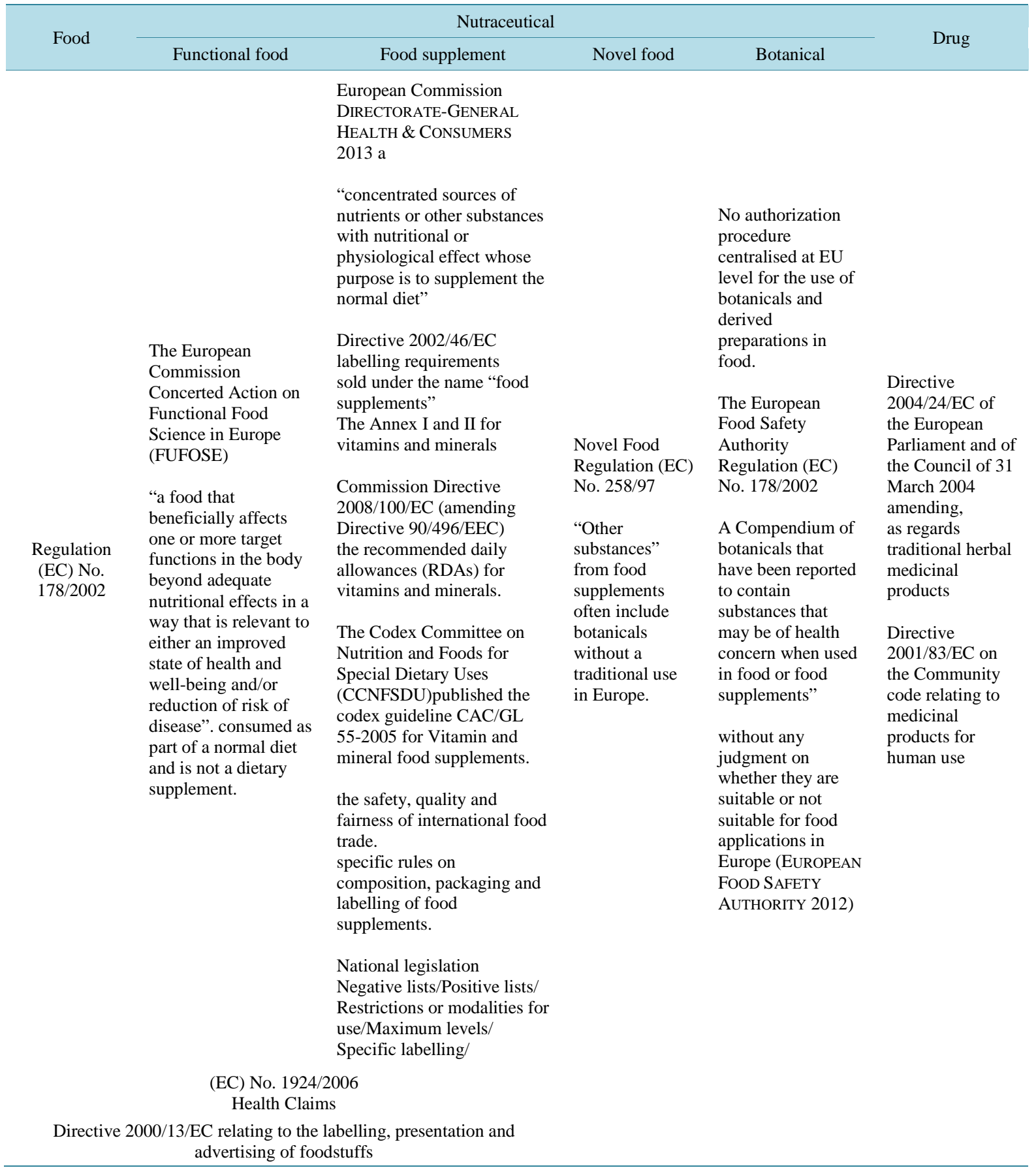

In China and India as well as England, Germany, France and Japan, botanicals are recognised as some form of traditional medicine. Traditional medicine is largely a cultural perspective and embraces local traditions and customs of use. A number of countries are increasingly interested in a traditional medicines class (the US among them), as it opens a relatively inexpensive way to sell a recognised and regulated class of drugs that are not bound by the extraordinary expense of new drug review processes [29].

The EU legal system does not set out any kind of authorization procedure for the use of botanicals and derived preparations in food [30]. The use of botanicals and derived preparations in food has to comply with the general requirements set out in the Regulation laying down general principles and requirements of food law 
(Regulation (EC) No. 178/2002) [30].

The Directive 2004/24/EC of the European Parliament and of the Council (amended in March 2004) applies to the pharmaceutical legislation for traditional herbal medicinal products in a uniform method with a simplified registration procedure. However, the Directive guarantees a stricter control of the herbal medicinal preparations, which used to be tolerated as dietary supplements or even as foods on the market. Raw materials-herbs and granules of single herbs-for the production of individual Traditional Chinese Medicine (TCM) formulations in pharmacies are not affected by this Directive. But for imports of medicinal products, which are produced plantbased, and come from China or India, the same standards (quality, safety and efficacy) apply as for domestic products. In order to market a medical product a company must present documents including the results of physico-chemical, biological or microbiological tests as well as pharmacological and toxicological tests and clinical trials to the authorization [31]. This authorization procedure ensures the quality, safety and efficacy of the product. Further the registration of traditional herbal medicinal products is governed by § 39a (Drugs Act) AMG.

\section{Conclusions}

Nowadays, the health consciousness increased significantly. The worldwide market of nutrition supplements and health foods is larger than ever before. Nevertheless, strict and clear definitions of the terms "nutraceutical" and "botanical" are still missing. Clear rules, and a best universally and internationally valid regulation, would simplify the procedure companies have to face when entering the healthy-food-market. On top of that, it would simplify the export and import of these products worldwide [32], especially when it came to a Transatlantic Trade and Investment Partnership' (TTIP) between the US and Europe.

Especially for functional foods, Japan can be seen as leader in this sector. In the mid-1980s, they already introduced the new food category of FOSHU to their regulatory framework [33]. Foods for Specific Health Uses (FOSHU) are foods that are composed of functional ingredients that affect the structure/function of the body. These foods are used to maintain or regulate specific health conditions [...]” [33]. The US developed a complex regulatory framework for functional foods, but by now, there is no clear regulatory clarification. With regard to the legislation of nutraceuticals or functional foods the EU comes in last, there exists no specific regulation. At least the European Commission developed the Health Claims Regulation to regulate the health related claims on products to avoid consumer misleading. In contrast, in most of the member states food supplements are relatively well defined and regulated. But then again a universal definition and an internationally valid regulation to support the export and the import of food supplements are still missing.

\section{Acknowledgements}

The paper was funded to M.B. by a grant from “Forschung für die Praxis”, Hessisches Ministerium für Wissenschaft und Kunst.

\section{References}

[1] Hemwall, E.L. (2010) Increasing Access to Nonprescription Medicines: A Global Public Health Challenge and Opportunity. Clinical Pharmacology \& Therapeutics, 87, 267-269. http://dx.doi.org/10.1038/clpt.2009.279

[2] Robert Koch-Institut (2012) Die Gesundheit des Erwachsenen in Deutschland. Robert Koch-Institut, Berlin.

[3] Nicoletti, M. (2012) Nutraceuticals and Botanicals: Overview and Perspectives. International Journal of Food Sciences and Nutrition, 63, 2-6. http://dx.doi.org/10.3109/09637486.2011.628012

[4] Wrick, K.L. (2005) The Impact of Regulations on the Business of Nutraceuticals in the United States: Yesterday, Today, and Tomorow. In: Hasler, C.M., Ed., Regulation of Functional Foods and Nutraceuticals, A Global Perspective, Blackwell Publishing, Iowa, 3-36. http://dx.doi.org/10.1002/9780470277676.ch1

[5] Wildmann, R.E. (2001) Nutraceuticals: A Brief Review of Historical and Teleological Aspects. In: Wildmann, R.E., Ed., Handbook of Nutraceuticals and Functional Foods, CRC Press, Boca Raton, 1-12.

[6] Petroczi, A., Taylor, G. and Naughton, D.P. (2011) Mission Impossible? Regulatory and Enforcement Issues to Ensure Safety of Dietary Supplements. Food and Chemical Toxicology, 49, 393-402.

http://dx.doi.org/10.1016/j.fct.2010.11.014

[7] Fattinger, K. and Meier-Abt, A. (2003) Interaktionen Zwischen Phytopharmaka und Arzneimitteln. Schweizerisches Medizin-Forum, 29-30, 693-700.

[8] Tsai, H.-H., Lin, H.-W., Simon, P.A., et al. (2012) Evaluation of Documented Drug Interactions and Contraindications 
Associated with Herbs and Dietary Supplements: A Systematic Literature Review. International Journal of Clinical Practice, 66, 1056-1078. http://dx.doi.org/10.1111/j.1742-1241.2012.03008.x

[9] Gulati, O.P. and Ottaway, P.B. (2006): Legislation Relating to Nutraceuticals in the European Union with a Particular Focus on Botanical-Sourced Products. Toxicology, 221, 75-87. http://dx.doi.org/10.1016/j.tox.2006.01.014

[10] Kalra, E.K. (2003) Nutraceutical-Definition and Introduction. Journal American Association Scientists, 5, 27-28.

[11] Random House Kernerman Webster’s College Dictionary (2010) A: Nutraceutical. http://www.kdictionaries-online.com/DictionaryPage.aspx?ApplicationCode=18\&DictionaryEntry=nutraceutical\&Sear chMode=Entry \&TranLangs $=18$

[12] American Heritage Dictionary of the English Language (2011) A: Nutraceutical. http://www.ahdictionary.com/word/search.html?q=nutraceutical

[13] European Nutraceutical Association (ENA) The Term Nutraceutical. http://www.enaonline.org/index.php?lang=en\&path=about

[14] The Bureau of Nutritional Sciences, of the Food Directorate of Health Canada (2002) Policy Paper-Nutraceuticals/ Functional Foods and Health Claims on Foods. http://www.hc-sc.gc.ca/fn-an/label-etiquet/claims-reclam/nutra-funct_foods-nutra-fonct_aliment-eng.php

[15] Shahidi, F. (2009) Nutraceuticals and Functional Foods: Whole versus Processed Foods. Trends in Food Science \& Technology, 20, 376-387. http://dx.doi.org/10.1016/j.tifs.2008.08.004

[16] Office of Dietary Supplements (2011) Botanical Dietary Supplements. http://ods.od.nih.gov/factsheets/BotanicalBackground-HealthProfessional/

[17] Random House Kernerman Webster’s College Dictionary (2010) B: Botanical. http://www.kdictionaries-online.com/DictionaryPage.aspx?ApplicationCode=18\&DictionaryEntry=botanical\&Search Mode=Entry\&TranLangs=18

[18] American Heritage Dictionary of the English Language (2011) B: Botanical. http://www.ahdictionary.com/word/search.html?q=botanical

[19] Oxford Dictionaries (2013) Botanical. http://www.oxforddictionaries.com/definition/english/botanical

[20] Food and Drug Administration (2004) Review of Botanical Drug Products. http://www.fda.gov/downloads/AboutFDA/CentersOffices/OfficeofMedicalProductsandTobacco/CDER/ucm106137.p $\underline{\mathrm{df}}$

[21] Hasler, C.M. and Brown, A.C. (2009) Position of the American Dietetic Association: Functional Foods. Journal of the American Dietetic Association, 109, 735-746. http://dx.doi.org/10.1016/j.jada.2009.02.023

[22] Fulgoni, V. (2005) Health Claims: A U.S. Perspective. In: Hasler, C.M., Ed., Regulation of Functional Foods and Nutraceuticals: A Global Perspective, Blackwell Publishing, Iowa, 79-88. http://dx.doi.org/10.1002/9780470277676.ch5

[23] Heller, I.R. (2005) Functional Foods: Regulatory and Marketing Developments in the United States. In: Hasler, C.M., Ed., Regulation of Functional Foods and Nutraceuticals: A Global Perspective, Blackwell Publishing, Iowa, 169-199. http://dx.doi.org/10.1002/9780470277676.ch11

[24] Coppens, P., Delmulle, L., Gulati, O., Richardson, D., Ruthsatz, M., Sievers, H. and Sidani, S. (2006) Use of Botanicals in Food Supplements. Annals of Nutrition \& Metabolism, 50, 538-554. http://dx.doi.org/10.1159/000098146

[25] European Parliament and Council (2002) A: Regulation (EC) No 178/2002 of the European Parliament and of the Council of 28 January 2002 Laying down the General Principles and Requirements of Food Law, Establishing the European Food Safety Authority and Laying down Procedures in Matters of Food Safety. Official Journal of the European Communities, L31, 1-24.

[26] European Union (2010) Functional Foods. Publications Office of the European Union, Luxembourg.

[27] European Parliament and Council (2006) Regulation (EC) No 1924/2006 of the European Parliament and of the Council of 20 December 2006 on Nutrition and Health Claims Made on Foods. Official Journal of the European Union, L404, 9-25.

[28] Federal Office of Consumer Protection and Food Safety (2013) Food. http://www.bvl.bund.de/EN/01_Food/lm_food_node.html

[29] Israelsen, L. (2001) Regulations Influence on the Future of Botanicals. http://newhope360.com/botanicals/regulations-influence-future-botanicals

[30] European Food Safety Authority (2012) Botanicals. http://www.efsa.europa.eu/en/topics/topic/botanicals.htm

[31] European Parliament and Council (2002) B: Directive 2002/46/EC of the European Parliament and of the Council of 10 June 2002 on the Approximation of the Laws of the Member States Relating to Food Supplements. Official Journal 
of the European Communities, L183, 51-57.

[32] Fitzpatrick, K. (2005) Regulatory Issues Related to Functional Foods and Natural Health Products in Canada. In: Hasler, C.M., Ed., Regulation of Functional Foods and Nutraceuticals: A Global Perspective, Blackwell Publishing, Iowa, 213-226. http://dx.doi.org/10.1002/9780470277676.ch13

[33] Bailey, R. (2005) Funtional Foods in Japan: (FOSHU ("Foods for Specific Health Uses") and "Foods with Nutrient Function Claims”. In: Hasler, C.M., Ed., Regulation of Functional Foods and Nutraceuticals: A Global Perspective, Blackwell Publishing, Iowa, 247-261. http://dx.doi.org/10.1002/9780470277676.ch15 